Egyptian Journal of Aquatic Biology \& Fisheries

Zoology Department, Faculty of

Science, Ain Shams University,

Cairo, Egypt.

ISSN $1110-6131$

Vol. 24(3): $417-424$ (2020)

www.eiabf.iournals.ekb.eg

\title{
Studies on the infestation of Red Sea cultured Black Sea bream (Spondyliosoma cantharus ) with Caballerocotyla sp. (Monogenea; Capsalidae) parasite
}

\author{
Abeer E. Mahmoud ${ }^{1}$; Hussien A. Osman ${ }^{2, *}$; Mona S. Zaki ${ }^{2}$ and Alaa Z. Abubrika ${ }^{2}$ \\ ${ }^{1}$ Department of fish diseases, Animal Health Research Institute, Assuit Laboratory, Agriculture \\ Research Center, Dokki, Egypt. \\ ${ }^{2}$ Hydrobiology Department, Department, National Research Centre, Egypt. \\ *Corresponding Author: dr.hussien_osman@yahoo.com
}

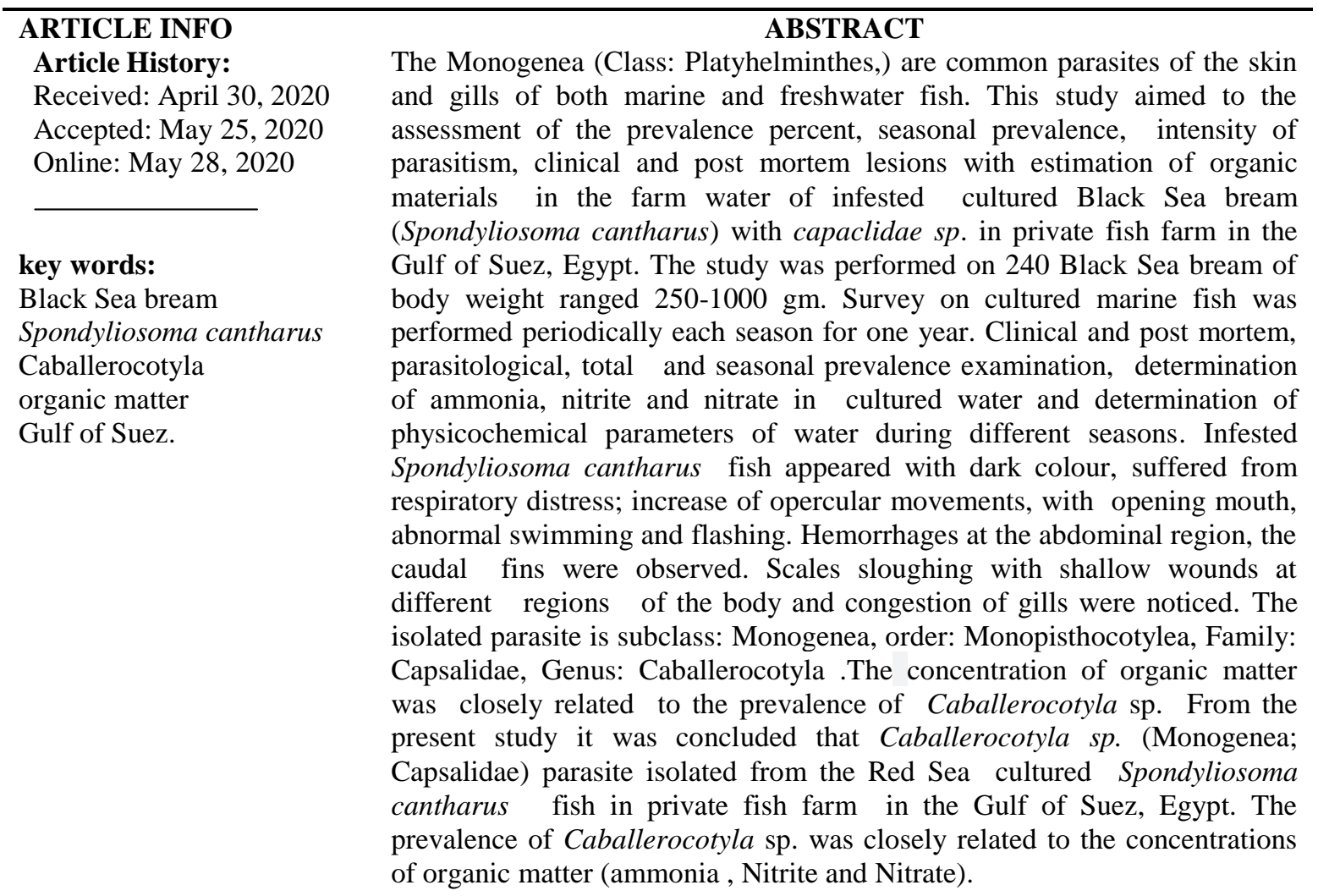

\section{INTRODUCTION}

The Monogenea (Class: Platyhelminthes,) are common parasites of the skin and gills of both marine and freshwater fish (Eissa, 2002 ; Buchmann and Bresciani, 2006; TrujilloGonzález et al., 2018). There are many different species, most of which have a narrow host range in nature. restricted to one species, genus, or family. However, this host specificity is often lost in aquaculture (Thoney and Hargis, 1991).

Heavy monogenean infections are usually index of poor sanitation and poor water quality (high ammonia or nitrite with organic pollution and low oxygen) (Osman et al., 2013). Monogeneans rapidly reproduce under these conditions. The doubling time for viviparous monogeneans can be as little as few hours. Reproductive rate is controlled by 
temperature, which, although not differ in the tropical aquarium, is important in less controlled environments (Noga, 2010 ).

Monopisthocotyleans feed mainly on the superficial layers of the host. This feeding activity is irritating and thus causes skin ulcers or focal reddening produced from excess mucus concentration, hemorrhage and epithelial hyperplasia (Kabata, 1985). Even little numbers of parasites can produce excess mucus. Some species can cause deep skin ulcers (Noga, 2010;Osman et al., 2013; Trujillo-González et al., 2018).

Identification of different monogenean species can be easily performed from the shape of hooks and adhesive structures. Monogenea are egg laying, producing freeswimming hooked ciliated larvae that hatch from eggs (oviparous). In others, larvae are produced from adult parasites (ovoviviparous) that often stay on the same host fish with their fathers (Eissa, 2002 , Morsy et al., 2011).

Present work aimed to investigate the prevalence percent, seasonal prevalence, intensity of parasitism, clinical and post mortem lesions with estimation of organic matter in the farm water of infested cultured Black Sea bream (Spondyliosoma cantharus) with Caballerocotyla sp. on private fish farm in the Gulf of Suez, Egypt.

\section{MATERIALS AND METHODS}

\section{Study area:}

Study was performed in private fish farm for culturing Black Sea bream $(S$. cantharus) at the Gulf of Suez, Suez governorate. This fish farm had 12 cement ponds used for culturing fishes. Each pond measured $5 \times 8 \mathrm{~m}^{2}$. Present study was performed on 240 Black Sea bream of body weight ranged 250-1000 gm. Survey on cultured marine fish was performed periodically each season for one year.

\section{Clinical and post mortem examinations :}

Swimming, respiration, external body and gills of the collected fish were examined (Lucky,1977); then fish were transported alive in large plastic ice box to the laboratory at Hydrobiology Department, National Research Centre, Dokki, Giza, Egypt.

\section{Parasitological examination :}

Scrapings from body surface; skin, fins and gills of live fish were taken with sea water and examined using compound microscope, searching for ecto-parasites. Gills were separated from the fish, and the gill filaments were cut out and placed in Petri dish full of filtered sea water for examination for monogenea parasites. Isolated monogenea cleared and preserved in $70 \%$ ethyl alcohol for processing and staining with carmine (Lucky, 1977).

\section{Total and seasonal prevalence:}

Along the year, infested Black Sea bream (S. cantharus) With Caballerocotyla sp was recorded as a total prevalence and recorded in each season with estimation of the density of infection as follows: Heavy infestation (+++) (more than 5 parasites/ field), Moderate infestation (++) (2-5 parasites/ field) \& Light infestation (+) (1 parasite/field) in each season.

Determination of ammonia, nitrite and nitrate and other physico-chemical parameters in cultured water:

Ammonia, nitrite and nitrate were measured in samples of water collected in each season using Hach model DR/2000. Also water temperature, dissolved oxygen, salinity and $\mathrm{pH}$ were measured using JENWAY 9200.

\section{RESULTS}

\section{Clinical sings and post mortem lesions :}

Infested $S$. cantharus fish appeared with dark colour, suffered from respiratory disturbance; as increase of opercular movements, surfacing, gulping the atmospheric air 
or jumping outside water with opening mouth, abnormal swimming and flashing (Fig. 1). Other observed lesions include: 1) Hemorrhages at the base of fins and the abdominal region; 2) Hemorrhages at the caudal peduncle and caudal fins; 3) Scales loss and ulcers at different regions of the body (Fig. 1), and 4) sever congestion of gills.

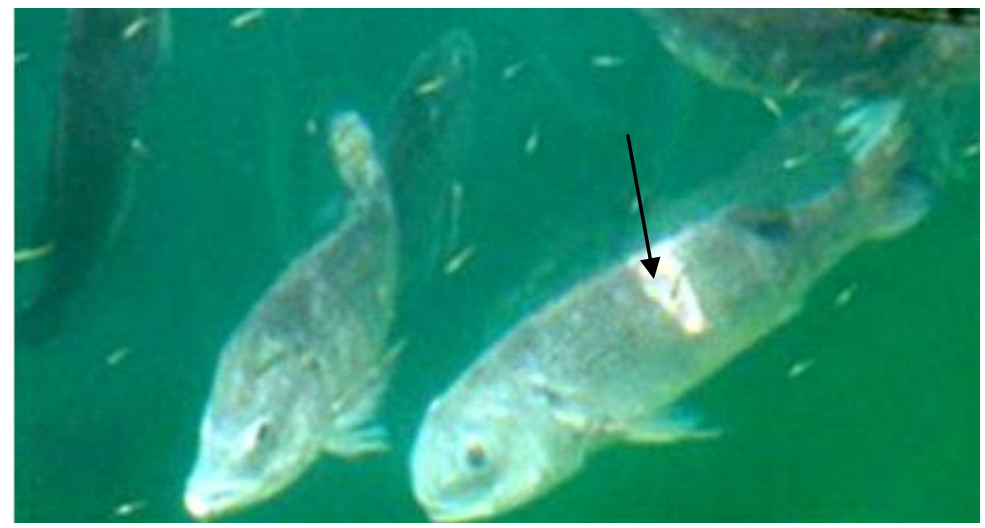

Fig.1: Showing black Sea bream swimming and suffered from ulcers (arrow)

\section{Identification of the isolated parasites :}

Isolated parasites identification mainly depending upon the characteristic morphology, it is dorsoventrally flat (no body cavity), compressed platyhelminthes worms hermaphrodite have male and female organs, It is oviparous laying fertilized eggs. The anterior part called prohaptor composed from large 2 adhesive organs help the parasite in movement and feeding and 2 pairs of eye spots ( Fig. 2,A). While the posterior attachment organ, or opisthaptor, appears as a single distinct unit composed of several large centrally, located sclerotized anchors and small marginal hooklets (for piercing host tissue) (Fig. 2, B). The isolated parasite is subclass: Monogenea, order: Monopisthocotylea, Family: Capsalidae, Genus: Caballerocotyla (whole worm attached to the gill filaments) (Fig. 2 C).

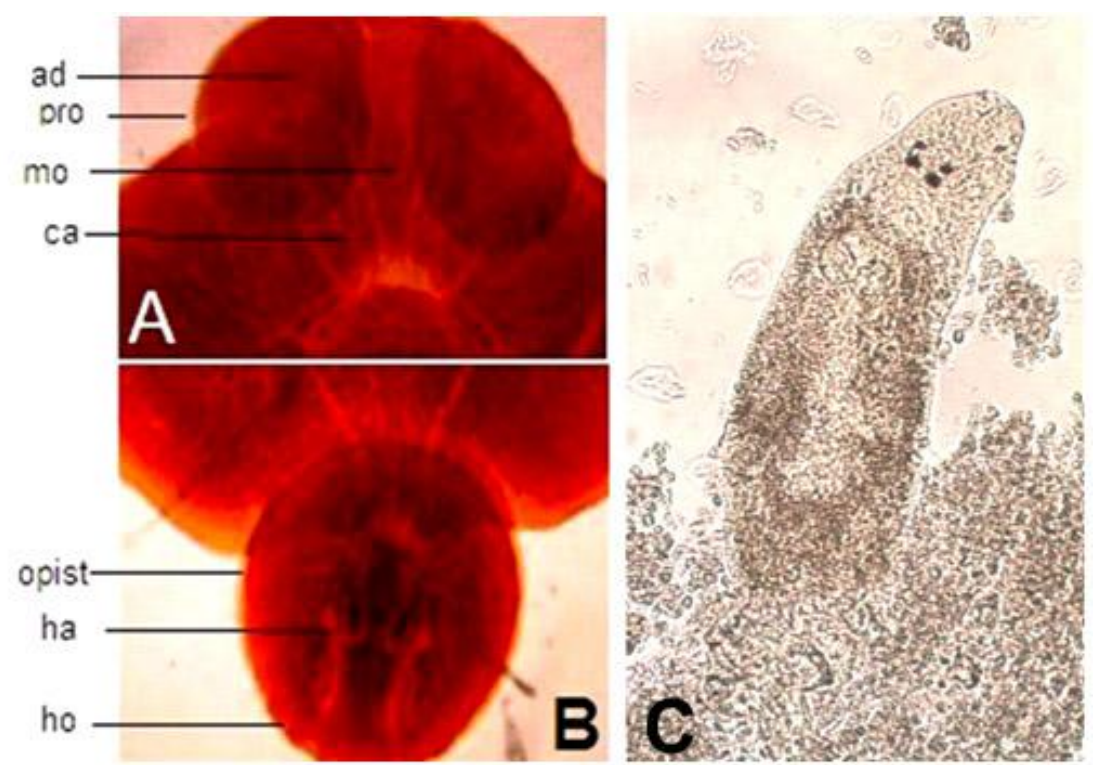

Fig. 2. A) anterior end of Caballerocotyla sp. ad.; adhesive organ, pro.; prohaptor, mo.; mouth and ca. adhesive canals. B) posterior part opist.; opisthaptor, ha.; hamulus, ho.; marginal hooklets stained with carmine and C) wet mount of whole worm of Caballerocotyla $s p$. attached with gill filament. 


\section{Prevalence of Caballerocotyla sp. :}

In the period of survey ( nearly one year ) out of 240 examined S. cantharus fish 62 fish infested with Caballerocotyla sp. (Monogenea: Capasilidae) in all seasons of the year with total percentage 25.83 table 1 .

Table 1: Prevalence of Caballerocotyla sp. in Spondyliosoma cantharus fish

\begin{tabular}{|c|c|c|}
\hline Total No. of examined fishes & No. of infested fishes & Percent of infested fishes \% \\
\hline 240 & 62 & 25.83 \\
\hline
\end{tabular}

\section{Seasonal variations of Caballerocotyla sp. infestation :}

During present study, the total number of the examined fish was 240 (i.e. 60 fish/season). As mentioned previously, the number of infested fish with monogenea was 62 with total percentage of $25.83 \%$. Regarding the seasonal infestation (Table 2), the highest season of infestation was summer with percentage of $35 \%$ (out of 60 examined fish, 21 infested fish were recorded), followed by spring with percentage of $30 \%$ (out of 60 examined fish, 18 infested fish were recorded), followed by autumn with percentage of $23.33 \%$ (out of 60 examined fish, 14 infested fish were recorded) and the lowest infestation rate was recorded in winter with percentage of $15 \%$ (out of 60 examined fish 9 infested were recorded).

Table 2: Seasonal variations of Caballerocotyla sp. Infestation

\begin{tabular}{|c|c|c|c|}
\hline Season & No. of examined fishes & No. of infested fishes & \% of infested fishes \\
\hline Summer & 60 & 21 & 35 \\
\hline Autumn & 60 & 14 & 23.33 \\
\hline Winter & 60 & 9 & 15 \\
\hline Spring & 60 & 18 & 30 \\
\hline Total & 240 & 62 & 25.83 \\
\hline
\end{tabular}

\section{Degrees of infestation (intensity) during different seasons :}

There is a wide range of severity in infestation during different seasons (Table 3). Concerning the light infestation rate ( 1 parasite /field) the highest percentage was recorded at winter $66.67 \%$ followed by spring $50.00 \%$ followed by autumn $35.71 \%$ while the lowest percentage was recorded at summer $33.33 \%$. Regarding the moderate infestation (2-5 parasite /field) the highest percentage was recorded at summer $28.57 \%$ followed by spring $27.78 \%$ followed by winter $22.22 \%$ while the lowest percentage was recorded in autumn $21.43 \%$. While the heavy infestation rate (more than 5 parasites / field). The highest percentage was recorded at autumn $42.86 \%$ followed by summer $38.10 \%$ followed by spring $22.22 \%$ while the lowest percentage was recorded at winter $11.11 \%$.

Table 3: Degrees of infestation during different seasons

\begin{tabular}{|c|c|c|c|c|c|c|c|}
\hline \multirow{3}{*}{ Season } & \multicolumn{2}{|c|}{$\begin{array}{c}\text { Light infestation (+) } \\
\text { (1 parasite/field) }\end{array}$} & \multicolumn{2}{|c|}{$\begin{array}{c}\text { Moderate infestation } \\
(++)\end{array}$} & \multicolumn{2}{|c|}{$\begin{array}{c}\text { Heavy infestation (+++) } \\
\text { (2-5 parasites/ field) }\end{array}$} & $\begin{array}{c}\text { Total } \\
\text { field) }\end{array}$ \\
\cline { 2 - 7 } & No. of infest. & $\%$ & No. of infest. & $\%$ & No. of infest. & $\%$ & \\
fish \\
\hline Summer & 7 & 33.33 & 6 & 28.57 & 8 & 38.10 & 21 \\
\hline Autumn & 5 & 35.71 & 3 & 21.43 & 6 & 42.86 & 14 \\
\hline Winter & 6 & 66.67 & 2 & 22.22 & 1 & 11.11 & 9 \\
\hline Spring & 9 & 50.00 & 5 & 27.78 & 4 & 22.22 & 18 \\
\hline & 27 & 43.55 & 16 & 25.81 & 19 & 30.64 & 62 \\
\hline
\end{tabular}

Physicochemical parameters of water during different seasons:

The concentrations of dissolved oxygen were ranged from $7.5 \mathrm{ppm}$ in summer to $9.0 \mathrm{ppm}$ during winter, while salinity ranged from $32 \mathrm{ppt}$ during, summer and spring to

$36 \mathrm{ppt}$ in winter, on the other hand $\mathrm{pH}$ ranged from 7.2 in summer and 7.5 during 
winter, and water temperature ranged from $21-23{ }^{\circ} \mathrm{C}$ during autumn to $26-28{ }^{\circ} \mathrm{C}$ in summer (Table 4).

Table 4: Averages of physicochemical parameters of water during different seasons

\begin{tabular}{|c|c|c|c|c|}
\hline Season & Water temperature & $\begin{array}{c}\text { Dissolved } \\
\text { oxygen }\end{array}$ & Salinity & pH \\
\hline Summer & $26-28^{\circ} \mathrm{C}$ & $7.5 \mathrm{ppm}$ & $32 \mathrm{ppt}$ & 7.2 \\
\hline Autumn & $21-23^{\circ} \mathrm{C}$ & $7.8 \mathrm{ppm}$ & $35 \mathrm{ppt}$ & 7.4 \\
\hline Winter & $22-24^{\circ} \mathrm{C}$ & $9.0 \mathrm{ppm}$ & $36 \mathrm{ppt}$ & 7.5 \\
\hline Spring & $24-26^{\circ} \mathrm{C}$ & $8.0 \mathrm{ppm}$ & $32 \mathrm{ppt}$ & 7.3 \\
\hline
\end{tabular}

\section{Organic matter concentration during different seasons :}

The concentrations of organic matter were closely related and correlated to the prevalence of Caballerocotyla sp. The highest concentration of ammonia $\left(\mathrm{NH}^{3}\right)$ was recorded in summer $(0.015 \mathrm{mg} / \mathrm{l})$ and the lowest concentration was recorded during winter $(0.009 \mathrm{mg} / \mathrm{l})$. The highest concentration of nitrate $\left(\mathrm{NO}_{3}\right)$ was recorded during summer $(12.66 \mathrm{mg} / \mathrm{l})$ and the lowest concentration was recorded in winter $(5.40 \mathrm{mg} / \mathrm{l})$. The highest concentration of nitrite $\left(\mathrm{NO}_{2}\right)$ was recorded in summer $(0.14 \mathrm{mg} / \mathrm{l})$ and the lowest concentration was recorded in winter $(0.08 \mathrm{mg} / \mathrm{l})$ (Table 5).

Table 5 : Averages of organic matter concentration during different seasons

\begin{tabular}{|c|c|c|c|}
\hline Season & $\begin{array}{c}\text { Free ammonia }\left(\mathrm{NH}^{3}\right) \\
\mathrm{mg} / \mathrm{l}\end{array}$ & $\begin{array}{c}\text { Nitrate }\left(\mathrm{NO}_{3}\right) \\
\mathrm{mg} / \mathrm{l}\end{array}$ & $\begin{array}{c}\text { Nitrite }\left(\mathrm{NO}_{2}\right) \\
\mathrm{mg} / \mathrm{l}\end{array}$ \\
\hline Summer & 0.015 & 12.66 & 0.14 \\
\hline Autumn & 0.010 & 9.20 & 0.11 \\
\hline Winter & 0.009 & 5.40 & 0.08 \\
\hline Spring & 0.014 & 10.80 & 0.12 \\
\hline
\end{tabular}

\section{DISCUSSION}

The fish exposed to many diseases like any of other organisms. In recent times these diseases began to draw the attention of many researchers, especially after the intensification of fish farming in private fish farms. Ectoparasites is considered one of the pathogens that represent a big problem in the process of aquaculture because of the large economic losses either through direct or indirect (Woo , 1995; Eissa,2002; Noga, 2010).

Monogeanean parasites cause mortality of fish because their life cycle is simple, multiply rapidly and numbers are plentiful in short time, especially if there environmental factors appropriate to do so. The impact of single - parent worms affect the work of the different organs of fish such as osmotic change, or may lead to the entry of many other pathogens, or it may lead to mortality or decrease in growth rates of fish (Eissa,2002; Osman, et al., 2013). Present study aimed to investigate the prevalence, seasonal prevalence, density of parasites, clinical signs and post mortem lesions with estimation of organic matter in the cultured water in infested cultured Black Sea bream (S. cantharus) with Caballerocotyla sp. in private fish farm at the Gulf of Suez, Egypt.

Regarding the clinical sings and post mortem lesions, present study revealed that infested $S$. cantharus fish appeared with dark color suffered from respiratory distress as increase of opercular movements surfacing, abnormal swimming and flashing. Hemorrhages at the base of fins and the abdominal part, as well as hemorrhages at the caudal fins, were observed. Scales loss and shallow ulcers at different region of the 
body and sever congestion of gill lamellae, were noticed. The present results nearly agree with Eissa (2002), Noga, (2010) and Osman, et al.(2013) who reported that captive brood stock of grouper, Taradi collected from Red Sea coast, Jeddah demonstrated clinical infection with a monogenean parasite Benedenia epinephelea.. Monopisthocotylea infections on captive fish can be associated with reduced appetite, stunting of growth and emaciation. Captive fish can suffer stress, particularly if host densities are high or if fish are handled regularly (e.g. routine husbandry practices in aquaculture; aquarium touch tanks), exacerbating Monopisthocotylea infections (Rohde, 2005). Attachment and feeding by large numbers of Monopisthocotylea on fish 'skin' and gills can injure host epithelial cells faster than tissue regenerates. Mechanical irritation by significant 'skin' Monopisthocotylea populations probably occurs because infected fish may rub against hard substrates (tank or cage structures; bottom sediment). Progressive symptoms and damage to 'skin' by heavy infections may include: dark 'skin' patches from parasite feeding activities; excess mucus secretion; compression, erosion or removal of epithelium; loose scales; dermis injuries such as hemorrhages, open sores and ulcers exposing connective and muscle tissue; osmotic problems. On gills, significant Monopisthocotylea burdens can lead to increased mucus production and epithelial inflammation. (Eissa, 2002). Large Monopisthocotylea populations on skin or gills have been associated with mortalities of captive fish, but damage they inflict is open to secondary infections and perhaps viruses, bacteria and other microorganisms mostly kill infected hosts (Osman, et al., 2013).

Concerning the identification of the isolated parasites, present study displayed that isolated parasites was identified mainly basing upon the characteristic morphology. It is dorso-ventrally flat (with no body cavity), compressed worms platy helminthes, hermaphrodite have male and female organs, It is oviparous laying fertilized eggs, The anterior part called prohaptor composed from large 2 adhesive organs help the parasite in movement and feeding. While the posterior attachment organ, or opisthaptor, appears as a single distinct unit composed of several large centrally, located sclerotized anchors and small marginal hooklets (for piercing host tissue). The isolated parasite is subclass: Monogenea, order : Monopisthocotylea, Family : Capsalidae, Genus: Caballerocotyla the results confirmed by Morsy et al. (2011) and (Osman, et al., 2013) .

Concerning the prevalence of Caballerocotyla sp., present study displayed that out of 240 examined $S$. cantharus fish, 62 fish infested with Caballerocotyla sp. (Monogenea: Capasilidae) in all seasons of the year with total percentage of $25.83 \%$. The present results nearly agree with Eissa et al.,2010, Whittington et al. (2000 a, b), Whittington and Cribb (2001), Morsy et al.(2011) and Osman et al.(2013) who record same or different prevalence may be due to different fish species, locality and geographical distribution .

Present study recorded that there was wide seasonal variations of Caballerocotyla sp. infestation which recorded as out of 240 S. cantharus fish examined, 60 fish in each season the infested fish was 62 with total percentage of $25.83 \%$, regarding seasonal infestation the highest season of infestation was summer, with percentage of $35 \%$, followed by spring with percentage of $30 \%$, followed by autumn with percentage of $23.33 \%$ and the lowest infestation rate was recorded in winter, with percentage of $15 \%$, The present results nearly agree with that obtained by Osman, (2005). This may be due to that high water temperature make enhancement of the life cycle of Caballerocotyla $\mathrm{sp}$ increasing prevalence and intensities of parasitism with Caballerocotyla (Noga,2010). There is a wide range of severity in infestation during different seasons (Table 3 ).

Concerning the light infestation rate (1 parasite /field) the highest percentage was recorded at winter $66.67 \%$ followed by spring $50.00 \%$ followed by autumn $35.71 \%$ while the lowest percentage was recorded at summer $33.33 \%$. Regarding the moderate infestation (2-5 parasite /field) the highest percentage was recorded at summer $28.57 \%$ followed by spring $27.78 \%$ followed by winter $22.22 \%$ while the lowest percentage was recorded in autumn $21,43 \%$. While the heavy infestation rate (more than 5 parasites / 
field). The highest percentage was recorded at autumn $42.86 \%$ followed by summer $38.10 \%$ followed by spring $22.22 \%$ while the lowest percentage was recorded at winter $11.11 \%$. Intensity of infestation firmly closed with ecological reasons and stress factors causing infestation, from present study it was noticed that high infestation is always correlated with water temperature which is usually occur in summer and spring where enhancing life cycle increasing population and densities of monogenea (Woo,1995; Eissa, 2002; Osman, 2005 and Eissa, 2010).

Concerning the organic matter concentration during different seasons, present study displayed that the concentrations of organic matter were closely related and correlated to the prevalence of Caballerocotyla sp. The highest percentage concentration of ammonia $\left(\mathrm{NH}^{3}\right)$ was recorded at summer $(0.015 \mathrm{mg} / \mathrm{l})$ and the lowest concentration was recorded at winter $(0.009 \mathrm{mg} / \mathrm{l})$. The highest percentage concentration of Nitrate $\left(\mathrm{NO}_{3}\right)$ was recorded at summer $(12.66 \mathrm{mg} / \mathrm{l})$ and the lowest concentration was recorded at winter $(5.40 \mathrm{mg} / \mathrm{l})$. The highest percentage concentration of Nitrite $\left(\mathrm{NO}_{2}\right)$ was recorded at summer $(0.14 \mathrm{mg} / \mathrm{l})$ and the lowest concentration was recorded at winter $(0.08 \mathrm{mg} / \mathrm{l})$. These results agree with Osman (2005) Rohde (2005) and Noga, (2010) who reported that heavy monogenean infestations are usually indicators of poor sanitation and deteriorating water quality (overcrowding, high ammonia or nitrite, organic pollution, or low oxygen). They can rapidly reproduce under such conditions. The doubling time for viviparous monogeneans can be as little as 24 hours. reproductive rate is also controlled by temperature.

\section{CONCLUSION}

From the present study it was concluded that Caballerocotyla sp. (Monogenea; Capsalidae) parasite isolated from the Red Sea cultured Spondyliosoma cantharus fish in private fish farm, Gulf of Suez, Egypt. Infested fish was observed with respiratory distress, abnormal swimming with hemorrhages and ulcers at the body surface and abdominal region. The highest prevalence and densities of infestation were recorded in summer season. The prevalence of Caballerocotyla sp. was closely related to the concentrations of organic matter (ammonia, Nitrite and Nitrate).

\section{REFERENCES}

Buchmann, K. and Bresciani J. (2006). Monogenea (Phylum Platyhelminthes) . In: Fish Diseases and Disorders, Vol. 1 . Protozoan and Metazoan Infections , $2^{\text {nd }}$ ed . ( PTK Woo , ed.), CABI, Oxford., pp. $297-344$.

Eissa, I. A. M.; Gado, M. S.; Lila, A. M, Noor El Deen, A. I. E. (2010).The External Parasitic Diseases Prevailing in Male and Monosex Tilapias in Kafr El-Sheikh Governorate Fish Farms. The $5^{\text {th }}$ Inter. Conf. Vet. Res. Div., NRC, Cairo, Egypt., 2224.

Eissa, I. A. M. (2002). Parasitic fish diseases in Egypt El-Nahda El-Arabia Publisher, 32 Abd El-Khalek., Tharwat street, Cairo, Egypt.

Kapata (1985). Parasites and Diseases of Cultured Fish in the Tropics. Taylor and Francis, London.

Lucky, Z. (1977). Methods for the diagnosis of fish diseases, Amerind. publishing Co., P. V. T. Ltd., New Delhi, Bombay, India. 
Morsy, K.; Sayed, A. M.; Fathy. A. G.; Bashtar, A. R.; Ali A. G. and Rania A. G., (2011). First record of Benedenia sciaenae (Monogenea: Capsalidae) infecting the brown-spotted grouper fish Epinephelus chlorostigma (Family: Serranidae) from the Red Sea in Egypt. Life Science Journal, 8 (4): 245-252.

Noga, E J. (2010). Fish disease Diagnosis and Treatment. Mosby-yearbook, Inc. watsworth publishing Co., USA. $2^{\text {nd }}$ ed.

Osman, H. A. M. ; Abd El-Mohsen, H. M. and Ahmed, M. E. E. (2013). Infestation of Red Sea Cultured Plectropomus areolatus Broodstock with Benedenia epinepheli (Yamaguti1937) Parasite in Saudi Arabia with Some Treatment Trails Global Veterinaria, 11 (2): 160-167.

Osman, M. A. H. (2005).Studies on Monogenasis among fishes. Ph .D. Thesis, Fac. Vet. Med., Suez Canal University.

Rohde, K. (2005). MARINE PARASITOLOGY Published by CABI Publishing, a Division of $\mathrm{CAB}$ International.

Thoney, D. A.and Hargis, W. J. Jr. (1991). Monogenea (Platyhelminthes) as hazards for fish in confinement. Annual Review of Fish Diseases, 1, 133-153.

Trujillo-González, A. ; Becker, J. A. ; Vaughan, D. B. and Hutson, K. S.(2018). Monogenean parasites infect ornamental fish imported to Australia Parasitology Research, 117(4), pp 995-1011.

Whittington, I.D.; Chisholm, L.A. and Rohde, K.(2000b). The larvae of Monogenea (Platyhelminthes). Advances in Parasitology, 44, 139-232.

Whittington, I.D.; Cribb, B.W.; Hamwood, T.E. and Halliday, J.A. (2000a). Hostspecificity of monogenean (platyhelminth) parasites: a role for anterior adhesive areas ? International Journal for Parasitology, 30, 305-320.

Whittington, I.D. and Cribb, B.W. (2001). Adhesive secretions in the Platyhelminthes. Advances in Parasitology, 48, 101-224.

Woo, P. T. K. (1995).Fish diseases and disorders. CAB, Int. Wallingford, Oxon, Uk.

\section{ARABIC SUMMARY}

Caballerocotyla sp. دراسات على الإصابة فى أسماك الدنيس الأسود المستزرعة فى البحر الأحمر بطفيل

عبير عزت محمود' ، حسين عبد الفتاح محمد عثمان’ ، منى سعد زكى ‘ ، علاء الدين زكريا أبو بريكة'

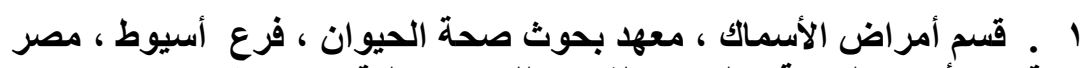

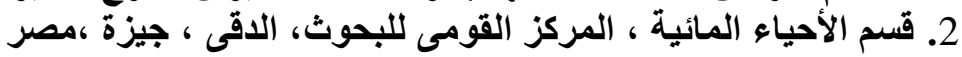

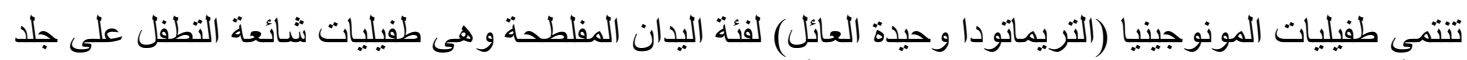

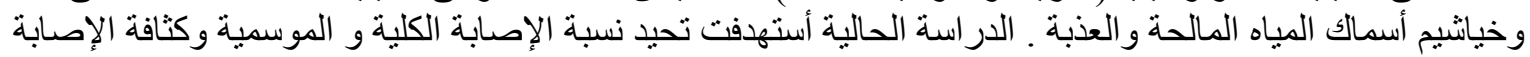

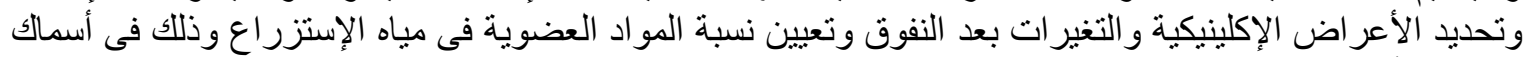

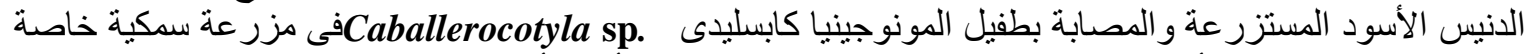

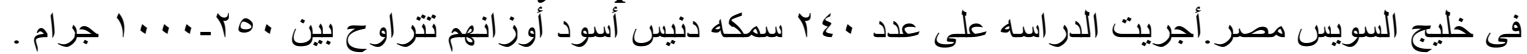

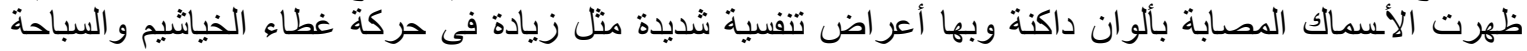

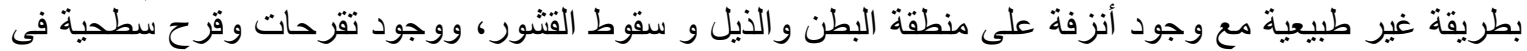

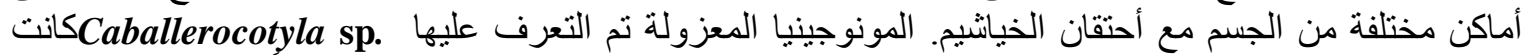

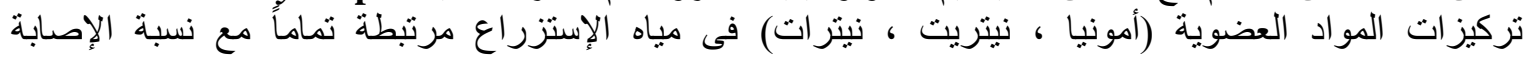
بالمونوجينيا. 